\title{
Bacillus amylolyticus sp. nov., nom. rev., Bacillus lautus sp. nov., nom. rev., Bacillus pabuli sp. nov., nom. rev., and Bacillus validus sp. nov., nom. rev.

\author{
L. K. NAKAMURA
} \\ Northern Regional Research Center, Agricultural Research Service, U.S. Department of Agriculture, Peoria, Illinois 61604
}

\begin{abstract}
The names "Bacillus amylolyticus" Choukévitch 1911, "Bacillus lautus" Batchelor 1919, "Bacillus pabuli" Schieblich 1923, and "Bacillus validus" Bredemann and Heigener 1935 were not included on the Approved Lists of Bacterial Names. The names Bacillus amylolyticus, Bacillus lautus, Bacillus pabuli, and Bacillus validus are here revived; all of these names except Bacillus amylolyticus are used for the same taxa to which they were originally applied. The name Bacillus amylolyticus is applied to the taxon described by Kellerman and McBeth. The type strains of B. amylolyticus, B. lautus, B. pabuli, and B. validus are strains NRRL NRS-290, NRRL NRS-666, NRRL NRS-924, and NRRL NRS-1000, respectively.
\end{abstract}

Choukévitch (4), Batchelor (1), Schieblich (11), and Bredemann and Heigener (3) validly published descriptions of the new species "Bacillus amylolyticus," "Bacillus lautus," "Bacillus pabuli," and "Bacillus validus," respectively. Because the name $B$. amylolyticus was validly published in 1911, its use for a different species by Kellerman and McBeth in 1912 (7) was illegitimate. These four species were listed in Bergey's Manual of Determinative Bacteriology, 5th ed. (2). Because of an apparent oversight, " $B$. amylolyticus" Kellerman and McBeth, not " $B$. amylolyticus" Choukévitch, was listed. However, since they were poorly described, these species were excluded from subsequent editions of Bergey's Manual. Smith et al. (14) and Gordon et al. (6) reclassified " $B$. amylolyticus" Kellerman and McBeth and the three other species as Bacillus circulans strains. Except in the originally published description, the name " $B$. amylolyticus" Choukévitch has not appeared in the literature, and the locations of strains of this species are not known. The loss of the taxonomic status of the names was reinforced by exclusion from the Approved Lists of Bacterial Names published in 1980 (13).

Recent taxonomic studies have revealed that the guanineplus-cytosine $(\mathrm{G}+\mathrm{C})$ contents of the deoxyribonucleic acids (DNAs) of $B$. circulans sensu stricto ranged from 37 to 39 mol\% (10). Because those $B$. circulans strains that were originally classified as " $B$. amylolyticus," " $B$. lautus," " $B$. pabuli," and " $B$. validus" had $\mathrm{G}+\mathrm{C}$ contents ranging from 47 to $54 \mathrm{~mol} \%$, they were considered to be not related genetically to the type strain (10). In the present study, spectrophotometrically determined (5) DNA relatedness values confirmed that " $B$. amylolyticus," " $B$. lautus," " $B$. pabuli," and "B. validus" are not genetically related to each other, to $B$. circulans NRRL NRS-726 ${ }^{\mathrm{T}}(\mathrm{T}=$ type strain), or to the type strains of established species having similar $\mathrm{G}+\mathrm{C}$ contents, such as Bacillus coagulans NRRL NRS-609 ${ }^{\mathrm{T}}$, Bacillus macerans NRRL NRS-888 ${ }^{\mathrm{T}}$, Bacillus polymyxa NRRL NRS- $1105^{\mathrm{T}}$, and Bacillus stearothermophilus NRRL NRS- $18^{\mathrm{T}}$ (Table 1). Furthermore, each of the tentative species was shown to be represented by at least four genetically related strains (Table 1). Extensive characterization by the method of Gordon et al. (6) showed that each group is phenotypically distinct from the other groups and from $B$. circulans sensu stricto (10). However, all four groups and $B$. circulans shared the following characteristics: they were motile, catalase positive, gram positive, and facultatively anaerobic; they produced oval spores in swollen sporangia; they hydrolyzed starch; they acidified litmus milk; they fermented L-arabinose, cellobiose, D-fructose, Dgalactose, D-glucose, lactose, maltose, D-mannitol, D-mannose, melibiose, D-ribose, sucrose, trehalose, and D-xylose; they did not produce acetylmethylcarbinol, $\mathrm{H}_{2} \mathrm{~S}$, oxidases, or indole; and they did not degrade filter paper (cellulose) in nutrient broth, egg yolk lecithine, tyrosine, arginine, lysine, or ornithine. Furthermore, all five species formed agar colonies that were grayish white, translucent, smooth, circular, entire, and 1.0 to $2.0 \mathrm{~mm}$ in diameter after 3 days at $30^{\circ} \mathrm{C}$. The salient characteristics for differentiating the four groups and $B$. circulans are given in Table 2 .

Based on the data described above, the names Bacillus amylolyticus, Bacillus lautus, Bacillus pabuli, and Bacillus validus are revived, and each name except $B$. amylolyticus is used for the same taxon to which it was originally applied in accordance with Rules 27 and 28a and Provisional Rules $B_{2}$ and $\mathrm{B}_{3}$ of the International Code of Nomenclature of Bacteria (8). Because the revival is based on an examination of the original strain of Kellerman and McBeth, the name $B$. amylolyticus is applied to the taxon originally described by these authors.

The following descriptions include only the salient characteristic of the new species; the commonly shared characteristics are listed above.

Bacillus amylolyticus (am.y.lo.ly'ti.cus. L. n. amylum starch; Gr. adj. lyticus dissolving; M.L. masc. adj. amylolyticus starch dissolving) cells are rods that are 0.5 to $1.0 \mu \mathrm{m}$ wide by 3.0 to $6.0 \mu \mathrm{m}$ long.

Growth is not inhibited by $3 \% \mathrm{NaCl}$, by $0.001 \%$ lysozyme, or at $\mathrm{pH}$ 5.6. Most strains, including the type strain, are inhibited by $5 \% \mathrm{NaCl}$.

The optimum growth temperature is 28 to $30^{\circ} \mathrm{C}$, the maximum temperature is 40 to $45^{\circ} \mathrm{C}$, and the minimum temperature is 10 to $15^{\circ} \mathrm{C}$.

Urea is seldom hydrolyzed.

Nitrate is reduced to nitrite.

Acetate is utilized by most strains; citrate, fumarate, malate, and succinate are not utilized.

L-Rhamnose is seldom fermented.

The average $\mathrm{G}+\mathrm{C}$ content of the DNA is $53 \mathrm{~mol} \%$.

Habitat: soil (7). 
TABLE 1. DNA relatedness of "B. amylolyticus," "B. lautus," "B. pabuli," and "B. validus" strains

\begin{tabular}{|c|c|c|c|c|}
\hline \multirow[b]{2}{*}{ Strain } & \multicolumn{4}{|c|}{$\%$ Reassociation with DNA from: ${ }^{a}$} \\
\hline & $\begin{array}{l}\text { "B. amylolyticus" } \\
\text { NRRL NRS-290" }\end{array}$ & $\begin{array}{c}\text { "B. lautus" } \\
\text { NRRL NRS- } 666^{\mathrm{T}}\end{array}$ & $\begin{array}{c}\text { "B. pabuli" } \\
\text { NRRL NRS-924 }\end{array}$ & $\begin{array}{c}\text { "B. validus" } \\
\text { NRRL NRS- } 1000^{\mathrm{T}}\end{array}$ \\
\hline \multicolumn{5}{|l|}{ "B. amylolyticus"b } \\
\hline NRRL B-142 & 89 & 20 & 23 & 20 \\
\hline NRRL NRS-290 & $(100)^{c}$ & 18 & 3 & 8 \\
\hline NRRL NRS-359 & 100 & 11 & 11 & 15 \\
\hline NRRL NRS-1136 & 100 & 29 & 6 & 23 \\
\hline \multicolumn{5}{|l|}{ "B. lautus"b } \\
\hline NRRL NRS- $666^{\mathrm{T}}$ & 18 & $(100)$ & 3 & 13 \\
\hline NRRL NRS-676 & 12 & 75 & 19 & 18 \\
\hline NRRL NRS-678 & 3 & 70 & 3 & 23 \\
\hline NRRL NRS-679 & 5 & 84 & 13 & 17 \\
\hline NRRL NRS-1171 & 19 & 100 & 23 & 20 \\
\hline \multicolumn{5}{|l|}{ "B. pabuli",b } \\
\hline NRRL B-745 & 6 & 2 & 75 & 8 \\
\hline NRRL B-1373 & 18 & 5 & 82 & 19 \\
\hline NRRL B-1488 & 7 & 2 & 80 & 26 \\
\hline NRRL BD-536 & 15 & 3 & 72 & 19 \\
\hline NRRL BD-537 & 10 & 4 & 70 & 16 \\
\hline NRRL NRS-924 & 3 & 3 & $(100)$ & 16 \\
\hline \multicolumn{5}{|l|}{ "B. validus" $b$} \\
\hline NRRL NRS-625 & 7 & 16 & 12 & 97 \\
\hline NRRL NRS-639 & 23 & 10 & 20 & 97 \\
\hline NRRL NRS-838a & 13 & 20 & 17 & 100 \\
\hline NRRL NRS-839a & 25 & 23 & 10 & 100 \\
\hline NRRL NRS-1000 & 8 & 13 & 16 & $(100)$ \\
\hline B. circulans NRRL NRS- $726^{\mathrm{T}}$ & 10 & 2 & 14 & 3 \\
\hline B. coagulans NRRL NRS $-609^{\mathrm{T}}$ & 20 & 16 & 21 & 29 \\
\hline B. macerans NRRL NRS $-888^{\mathrm{T}}$ & 14 & 15 & 5 & 8 \\
\hline B. polymyxa NRRL NRS- $1105^{\mathrm{T}}$ & 26 & 29 & 18 & 9 \\
\hline B. stearothermophilus NRRL NRS-18 ${ }^{\mathrm{T}}$ & 29 & 25 & 14 & 22 \\
\hline
\end{tabular}

${ }^{a}$ Reassociation values are averages of two determinations.

${ }^{b}$ Histories of these strains are given in reference 9.

${ }^{c}$ The values in parentheses indicate that by definition the reassociation value was $100 \%$.

The type strain is strain NRRL NRS-290. Except for its inability to utilize acetate, the type strain is phenotypically identical to the species. It does not hydrolyze urea or ferment L-rhamnose.

Bacillus lautus (lau'tus. L. part. adj. lautus washed, splendid) cells are rods that are 0.5 to $1.0 \mu \mathrm{m}$ wide by 4.0 to $7.0 \mu \mathrm{m}$ long.

Growth is not inhibited by $5 \% \mathrm{NaCl}$ or by $0.001 \%$ lysozyme. No growth occurs at $\mathrm{pH} 5.6$

The optimum growth temperature is 28 to $30^{\circ} \mathrm{C}$, the maximum temperature is $35^{\circ}$ to $40^{\circ} \mathrm{C}$, and the minimum temperature is 5 to $10^{\circ} \mathrm{C}$.

Urea is hydrolyzed.

Nitrate is reduced to nitrite.

Acetate is utilized; citrate, fumarate, malate, and succinate are not utilized.

L-Rhamnose is fermented in addition to other carbohydrates.

The average $\mathrm{G}+\mathrm{C}$ content of the DNA is $51 \mathrm{~mol} \%$.

Habitat: human intestinal tracts (1) and soil (9).

The type strain is strain NRRL NRS-666. The description of this strain is identical to that of the species.

Bacillus pabuli (pa'bu.li. L. gen. n. pabuli of fodder) cells are rods that are 0.5 to $1.0 \mu \mathrm{m}$ wide by 2.0 to $4.0 \mu \mathrm{m}$ long.

Growth is not inhibited by $3 \% \mathrm{NaCl}$; not all strains are inhibited by $5 \% \mathrm{NaCl}$. Growth occurs at $\mathrm{pH}$ 5.6. Growth is inhibited by $0.001 \%$ lysozyme.

The optimum growth temperature is 28 to $30^{\circ} \mathrm{C}$, the maximum temperature is 35 to $40^{\circ} \mathrm{C}$, and the minimum temperature is 5 to $10^{\circ} \mathrm{C}$.
Casein is hydrolyzed by most strains, including the type strain.

Nitrate is not reduced to nitrite.

Acetate is utilized; citrate, fumarate, malate, and succinate are not utilized.

L-Rhamnose is fermented in addition to other carbohydrates.

The average $\mathrm{G}+\mathrm{C}$ content of the DNA is $49 \mathrm{~mol} \%$.

Habitat: fodder (11) and soil (9).

The type strain is strain NRRL NRS-924. The description of this strain is essentially identical to that of the species; it is inhibited by $5 \% \mathrm{NaCl}$.

Bacillus validus (val'i.dus. L. adj. validus strong, vigorous) cells are rods that are 0.5 to $1.0 \mu \mathrm{m}$ wide by 5.0 to 7.0 $\mu \mathrm{m}$ long.

Growth is inhibited by $3 \% \mathrm{NaCl}$ and $0.001 \%$ lysozyme. Growth takes place at $\mathrm{pH} 5.6$

The optimum growth temperature is 28 to $30^{\circ} \mathrm{C}$, the maximum temperature is 45 to $50^{\circ} \mathrm{C}$, and the minimum temperature is 5 to $10^{\circ} \mathrm{C}$.

Tween 80 and urea are hydrolyzed.

Nitrate is not reduced to nitrite.

Acetate, citrate, fumarate, malate, and succinate are utilized.

L-Rhamnose and D-sorbitol are fermented in addition to other carbohydrates.

The average $\mathrm{G}+\mathrm{C}$ content of the DNA is $54 \mathrm{~mol} \%$.

Habitat: soil (3).

The type strain is strain NRRL NRS-1000; its description is identical to that of the species. 
TABLE 2. Characteristics for differentiating "B. amylolyticus," B. circulans, "B. lautus," "B. pabuli," and "B. validus"

\begin{tabular}{|c|c|c|c|c|c|}
\hline Characteristic & $\begin{array}{l}\text { B. cir- } \\
\text { culans }\end{array}$ & $\begin{array}{l}\text { "B. amylo- } \\
\text { lyticus" }\end{array}$ & $\begin{array}{l}\text { "B. lau- } \\
\text { tus" }\end{array}$ & $\begin{array}{l}\text { "B.pab- } \\
\text { uli" }\end{array}$ & $\begin{array}{l}\text { "B. val- } \\
\text { idus" }\end{array}$ \\
\hline \multicolumn{6}{|l|}{ Growth at or in: } \\
\hline $3 \% \mathrm{NaCl}$ & $t^{b}$ & + & + & + & - \\
\hline $5 \% \mathrm{NaCl}$ & + & $\mathrm{v}$ & + & $\mathrm{v}$ & - \\
\hline pH 5.6 & + & + & - & + & + \\
\hline $\begin{array}{l}0.001 \% \text { Lyso- } \\
\text { zyme }\end{array}$ & - & + & + & - & - \\
\hline \multicolumn{6}{|l|}{ Hydrolysis of: } \\
\hline Casein & - & - & - & $\mathrm{v}$ & - \\
\hline Tween 80 & + & - & - & - & + \\
\hline Urea & - & $\mathrm{v}$ & + & - & + \\
\hline $\begin{array}{l}\text { Nitrate reduced } \\
\text { to nitrite }\end{array}$ & - & + & + & - & - \\
\hline $\begin{array}{l}\mathrm{pH}<5.5 \text { in } \\
\text { Voges-Pros- } \\
\text { kauer broth }\end{array}$ & + & + & + & + & - \\
\hline \multicolumn{6}{|l|}{ Utilization of: } \\
\hline Acetate & + & $\mathrm{v}$ & + & + & + \\
\hline Citrate & - & - & - & - & + \\
\hline Fumarate & + & - & - & - & + \\
\hline Malate & + & - & - & - & + \\
\hline Succinate & - & - & - & - & + \\
\hline \multicolumn{6}{|l|}{ Fermentation of: } \\
\hline D-Sorbitol & + & - & - & - & + \\
\hline L-Rhamnose & + & $\mathbf{v}$ & + & + & + \\
\hline $\begin{array}{c}\mathrm{G}+\mathrm{C} \text { content } \\
(\mathrm{mol} \%)^{d}\end{array}$ & $37-39$ & 53 & $50-52$ & $48-50$ & $53-54$ \\
\hline
\end{tabular}

${ }^{a}$ Data taken from reference 10 .

${ }^{b}+$, Positive; - , negative; $v$, variable with strain.

${ }^{c} \mathrm{pH}$ after 7 days at $30^{\circ} \mathrm{C}$ in Voges-Proskauer broth.

${ }^{d}$ Determined by buoyant density centrifugation (12).

\section{LITERATURE CITED}

1. Batchelor, M. D. 1919. Aerobic spore-bearing bacteria in the intestinal tract of children. J. Bacteriol. 4:23-34.
2. Bergey, D. H., R. S. Breed, E. G. D. Murray, and A. P. Hitchens (ed.). 1939. Bergey's manual of determinative bacteriology, 5th ed. The Williams \& Wilkins Co., Baltimore.

3. Bredemann, G., and H. Heigener. 1935. Bacillus validus Bredemann and Heigener. Zentralbl. Bakteriol. Parasitendk. Infektionskr. Hyg. Abt. 2 93:97-98.

4. Choukévitch, J. 1911. Etude de la flore bacterienne du gros intestin du cheval. Ann. Inst. Pasteur Paris 25:247-267, 345368.

5. DeLey, J., H. Cattoir, and A. Reynaerts. 1970. The quantitative measurement of DNA hybridization from renaturation rates. Eur. J. Biochem. 12:133-142.

6. Gordon, R. E., W. C. Haynes, and C. H. Pang. 1973. The genus Bacillus. Agriculture Handbook 427. U.S. Department of Agriculture, Washington, D.C.

7. Kellerman, K. F., and I. G. McBeth. 1912. The fermentation of cellulose. Zentralbl. Bakteriol. Parasitenkd. Infektionskr. Hyg. Abt. 2 34:485-494.

8. Lapage, S. P., P. H. A. Sneath, E. F. Lessel, V. B. D. Skerman, H. P. R. Seeliger, and W. A. Clark (ed.). 1975. International code of nomenclature of bacteria. 1975 Revision. American Society for Microbiology, Washington, D.C.

9. Nakamura, L. K., and J. Swezey. 1983. Taxonomy of Bacillus circulans Jordan 1890: base composition and reassociation of deoxyribonucleic acid. Int. J. Syst. Bacteriol. 33:46-52.

10. Nakamura, L. K., and J. Swezey. 1983. Deoxyribonucleic acid study of Bacillus circulans Jordan 1890 . Int. J. Syst. Bacteriol. 33:703-708.

11. Schieblich, M. 1923. Zwei aus Futterproben isolierte, bisher noch nicht beschrieben Bazillen. Zentralbl. Bakteriol. Parasitenkd. Infektionskr. Hyg. Abt. 2 58:204-207.

12. Schildkraut, C. L., J. Marmur, and P. Doty. 1962. Determination of the base composition of deoxyribonucleic acid from its buoyant density in CsCl. J. Mol. Biol. 4:430-443.

13. Skerman, V. B. D., V. McGowan, and P. H. A. Sneath (ed.). 1980. Approved lists of bacterial names. Int. J. Syst. Bacteriol. 30:225-420.

14. Smith, N. R., R. E. Gordon, and F. E. Clark. 1952. Aerobic sporeforming bacteria. Agriculture Handbook 16. U.S. Department of Agriculture, Washington, D.C. 